\title{
THE SUCCESS AND FAILURES OF SARI-SARI STORES: EXPLORING THE MINDS OF WOMEN MICRO-ENTREPRENEURS
}

Jonathan C. GANO-AN ${ }^{1 *}$

Gloria P. GEMPES²

Received: December 2019 | Accepted: December 2019 | Published: August 2020

Please cite this paper as: Gano-An, J. C., Gempes, G. P. (2020). The success and failures of sari-sari stores: Exploring the minds of women micro-entrepreneurs, Holistica Journal of Business and Public Administration, vol. 11, iss. 2, pp. 25-51

\begin{abstract}
In the past decades, the unprecedented number of women in entrepreneurship has been overwhelmingly increasing. This was fueled by their motivation to earn independently and to uplift their economic condition. This paper magnified the stories of success and failures of women micro entrepreneurs in managing their 'sarisari' stores. Informants of this multiple case study were five women micro-entrepreneurs who had been in business for at least five years. An in-depth interview was done and cross case analysis was employed. Results revealed that new investments, enhanced family income, productivity, and resourcefulness were the stories that they highlighted as success. On the stories of failures, they emphasized that business breakdowns and personal crisis once confronted their operation. They also revealed that failures framed them to be determined, faithful, diligent, and optimistic. Lastly, they shared significant insights that women entrepreneurs must be business oriented, develop people skills, and employ a strong will power. These women entrepreneurs have their own way of defining moments relative to success and failures in micro entrepreneurship. What is worth noting is the fact that the innumerable failures which confronted them shaped the entrepreneurial traits they now possessed and achieved the optimum success in their entrepreneurial journey.
\end{abstract}

Keywords: Women entrepreneurship, micro-enterprise, success and failures, sari-sari, Philippines

JEL Classification: M30

\section{Introduction}

In the context of a developing world such as the Philippines, the failures and consequences of the entrepreneurial activities faced by micro businesses such as "sarisari stores" seemed to be undermined in the scholarly discussions and the specifics on how these entrepreneurial opportunities are pursued are somehow ignored (Ucbasaran, Westhead, Wright, \& Flores, 2010). An increasing stream of entrepreneurship literature exhibited that business failure is a widespread phenomenon (Mathias, Williams, \& Smith,

\footnotetext{
${ }^{1}$ ganoan.jonathan@gmail.com

2 Professional Schools, University of Mindanao, Philippines, gpgempes@gmail.com

* Corresponding author
} 
2015) and women are underrepresented in business sector (Zamfir \& Hjálmarsdóttir, 2017).To this end, it is emphasized that the process of how businessmen learn from their past and how these entrepreneurial lessons shaped their skills and abilities is remarkably essential in pursuing their ventures (Cope, 2011; Jenkins, Wiklund, \& Brundin, 2014). Scholarly articles showed some major reasons that break or make the small-scale enterprises, the most common is how the business acquires its capitalization. It appears that loaned capital is more likely to be successful than those that come from aid which usually disappears within a short period of time (Judama, 2013).

About 99.6 percent of registered businesses in the Philippines are MSME's which employ 62.3 percent of the nation's workforce and large corporations only account for 0.4 percent. As a close alternative to unemployment, large portion of the marginalized has turned to entrepreneurship (Lafond, 2014). For women, their way to be self-sufficient is through venturing into a small-scale business and women entrepreneurship is now in focus. Establishing your own venture and being a manager of your own time and resources is such a wish of many especially those who wanted full independence. The moment you have initiated your entrepreneurial activity, growth and satisfactory performance is your next priority. Yet, chances of setbacks and consequences are always possible (Gillis, 2015).

The mushrooming of micro enterprises has significantly afforded livelihood opportunities especially for struggling Filipino households. Retail stores, widely known as "sari-sari" stores have flourished in the Philippines. These retail enterprises are typically small, home-based, and usually run by "Nanays" or mothers who do not take part in the realities of the formal sector and are plainly doing domestic responsibilities (Munoz, Raven, \& Welsh 2005). "Sari-sari" stores offer cheap prices, flexible credit terms, selling wide range of basic consumer goods and are commonly located in the streets and even corners.

The enactment of RA 9178, otherwise known as the "Barangay Micro Business Enterprises (BMBE) Act of 2002" was carefully designed to speed up the economic development of the Philippines through boosting the development of Barangay Micro Business Enterprises. The BMBE's are intended to act as seedbeds of Filipino entrepreneurs and it inspired the informal sector to participate in the mainstream economy by streamlining government restrictions, the involvement of local government units and the expedited awarding of benefits and incentives (Figueroa, 2018). Micro, Small and Medium Enterprises (MSME's) can be considered as key drivers of sustainable progress in the Philippines through generation of jobs, guaranteeing a more just distribution of profit, developing products that meet the consumer requirements of the fast-growing number of Filipino consumers.

Starting an enterprise and running it requires lot of skills. It calls for sacrifice in terms of money and time. This concept is in contrast in the Philippine context, mothers who are running their small business are mostly uneducated and do not undergo any formal training to carry out business. Some are compelled to engaged in this activity without considering the technical and business skills required in running a small enterprise. Although there are studies regarding the critical success factors of small and medium 
enterprises (Yusof \& Aspinwall, 2000) but there were no published works regarding the success and failures of micro enterprises which are managed by women entrepreneurs in the context of developing economy such as the Philippines. Hence, as business educators, we were compelled to conduct an in-depth inquiry regarding this matter.

\subsection{Purpose Statement}

The principal intention of this multiple case study was to explore and discover the deep reasons which support the success or survival and the practices that contributed to the failures of "sari-sari" stores managed by women micro entrepreneurs in the Municipality of Maragusan, ComVal. Hence, five key informants were interviewed about the challenges that confronted the operation of their enterprise and they were asked about their secrets to success. Enabling me to draw substantial information that contribute to the success or failures of "sari-sari" stores. We also searched for the existing system employed by women micro entrepreneurs in their daily business activities or processes. The focus areas are more on the management of risks, their credit terms, and financing atmosphere. This paper does not solely concentrate on the failures, but also on the causes of these failures that maybe utilized in outlining effective patterns and strategies that may ultimately lead to business success. This paper highlighted the success and failure stories of women micro entrepreneurs which could lead to help other women micro-entrepreneurs who are experiencing the same problem.

\subsection{Research Questions}

1. What are the success and failure stories of women micro entrepreneurs?

2. How do failures framed them to achieve success in managing their "sari-sari" stores?

3. What significant insights can the participants share to their peers?

\subsection{Theoretical Underpinnings}

This study is viewed in the perspective of the Resource-Based View (RBV) theory by Wernerfelt (1984). The theory asserts that tangible and intangible resources are the key for the excellent performance of the enterprise. This theory further suggests that it is more practical to utilize internal opportunities rather than acquiring new skills from outside opportunities. Applying RBV theory in the micro-enterprise context, it stresses that long-term survival and existence is basically dependent on the business's unique product offerings. Sufficient time is necessary to develop this uniqueness through nurturing the core competency of the firm. Too often, it has been widely accepted that micro businesses are repeatedly faced with inadequate resources and this compels them to continue doing business under financial and capability constraints (Phillipson, Bennett, Lowe, \& Raley 2004; Zucchella \& Siano, 2014). In addition, the issue on insufficient resources can force the enterprise to concentrate on short-term instead on long-term objectives, and prevent them to explore the lucrative opportunities in their economic environment.

Another significant theory considered in this paper is the Stage Models of SME's Growth by McMahon (1998). This model defines the development and success of small and 
medium enterprises. The development and success of Small and Medium Enterprises (SME's) consists of stages and segments of growth through which the enterprise may pass in a lifecycle of a business. This model is similar to the natural growth of a human person in which it began with birth and end with death. Under the stage model, the first tier is the start-up stage, followed by expansion, maturity and the final is diversification level.

\subsection{Delimitations and Limitations}

This study was confined within the Municipality of Maragusan where the respondents are located. The testimonies, narrations and feedbacks of the key informants were described and documented. The scope of the study primarily focused on the stories of failures and success among five different owners of "sari-sari" store business. The factor that serves as a limitation or the perceived weakness of this study was the number of informants since it was relatively small. With the limited number of the informants, we cannot guarantee that the gathered data represent the entire population more than to generalize the women micro-entrepreneurs in the Philippines. The data used in this study was limited only to the responses of five participants. Another constraint is that we cannot guarantee that the participants provided an honest response to the research questions.

\section{Materials and methods}

\subsection{Research Design}

The primary purpose of this qualitative multiple case study was to investigate the practices that made women micro-entrepreneurs successful and explored the challenges and failures in managing their "sari-sari" stores. With its suitability to achieve the goals and purpose of this study, we used a multiple case study method in this paper as this methodology provided a multi-dimensional evidence. In this study, a multiple case-study approach was used primarily for the following reasons. First, the approach allowed an indepth analysis of the business failures and enable unique patterns to develop (Gibbert \& Ruigrok, 2010). More so, Yin (2009) argued that results of a multiple case study are often regarded as a convincing evidence and the overall study was considered to be more robust. Multiple case method also provided cross-case comparisons that permits the recognize special patterns and themes (Andrade, 2009; Woodside, 2010).

Second, case studies were proven to be a suitable methodology to be used in a research topic that has an inadequate literature or those that has less insights, and often used to explore the multifaceted issues in real life situation (Cronin, 2014; Voss, 2010; Yin, 2009). As our research topic has a very limited literature and published findings, we believe the appropriateness of a qualitative multiple case study in this paper. Case studies are also best for examining circumstantial questions such as the one guiding the research endeavor (Voss, 2010; Woodside, 2010).

Third, when using a case study approach multiple data collection is possible and the case results are expressed in an in-depth and holistic way (Vohra, 2014). Based on the purpose 
and the nature of the research questions, the multiple case study method, which is placed within the umbrella of interpretive research paradigm, was chosen. According to Houghton, Casey, Shaw, and Murphy (2013), a case study method has the competence to utilize multiple research techniques, ability to do an inquiry with a set of limits in the chosen issue, and can investigate current issues, challenges and problems genuinely.

For Creswell (2013), he argued that a case study is an inquiry of a bounded system or multiple cases in a certain period of time using a comprehensive data collective approach allowing multiple informants to provide their views about the subject at hand. Information or data for the research maybe gathered through observation, interviews, audio-visual materials, reports and existing documents. Accordingly, case studies are also capable of foretelling conflicting results or might forecast similar outcomes in existing studies (Houghton et al., 2013). Through this, researchers will know the value and worth of the research findings (Graebner, Martin, \& Roundy, 2012). When each case is being compared to another, it can provide a rich literature highlighting the gaps and parallelism (Vannoni, 2015). An encompassing fact reveals that findings of a case study yield a strong and reliable information (Vu \& Feinstein, 2017). Other significant benefits of a case study may include theory development/creation if the data is purely grounded on realistic findings. Hence, multiple case study permits an extensive examination of research questions and theoretical development (Graebner et al., 2012).

\subsection{Research Participants}

The informants of this study were five women "sari-sari" store owners. Participants in this study were selected based on the following criteria: At least 30 years old, she must have been in business for at least 5 years and with a minimum capitalization of at least 1,000 pesos or approximately 20USD in the Municipality of Maragusan, Philippines. More so, other qualifying criteria for success in this study was based on the assets acquired, the degree of comfort they have experienced after their venturing into a "sari-sari" business, and the amount of the aggregate fulfilment they felt on the course of their entrepreneurial journey.

Informants who are operating less than five years and do not meet the capitalization requirement were excluded in the study. Participation of informants in this study was voluntary and their refusal to participate involved no penalty or loss of benefits. Furthermore, it was carefully explained that they may withdraw if they felt that questions are too harsh, inhumane and unrelated to the subject matter. Selected women entrepreneurs were asked about their experiences managing their enterprise within the specified period. A recording device was used during the interview so that all responses were documented accurately. Pseudonyms were allowed and the personal circumstances of the informants were held confidential. At least two outside informants for each case who know the subject were involved in the study. This was done for the purpose of triangulation.

In a study employing a qualitative research methodology, interviews were used to obtain, penetrate, and manifest meanings beyond appearance. This technique also entails actual 
HOLISTICA Vol 11, Issue 2, 2020, pp. 25-51

field immersion to ascertain continuing and rich relationship with the informants and by means of doing a theoretical contemplation to extensively tackle the issue of the research. Thus, small number of cases with less than 20 participants are enough to get the desired sample from the total population (Crouch \& Mckenzie, 2006).

The first informant was The Persistent Widow. Since early 2000 she has managed to fight poverty and raised her child by herself. She possessed a strong determination and courage to continue her duties as mother to her child and lived with a comfortable and convenient life using the fruits of her "sari-sari" business.

The Resourceful Supermom is the second participant. According to her, when her husband met an accident, she shouldered all the paternal and maternal duties at home. Due to being resourceful, she stayed afloat amidst the challenges and her "sari-sari" store is the biggest contributor to her success.

Back then, business is a just a hobby or a past time activity, however, when she got married, she saw a wide opportunity in a "sari-sari" business. The Dauntless Survivor's story is one of the most admirable when she proudly recounted how her four children obtained their degrees and survived with the daily challenges of her married life. At a retiring age, she is still managing her 30-year-old "sari-sari" business.

The Faithful ITpreneur is the fourth participant. Her strong devotion to God made her win over the trials and challenges. In her 30's she decided to venture into business for additional household income. She also decided to put up her own business instead of joining the workforce as she saw her great potential in engaging in micro business.

The fifth informant was given the pseudonym, Experimentrepreneur. Her engagement in micro enterprise business is a result of an experiment she once had back then. In her 50's she tried to look for lucrative opportunities and venturing into "sari-sari" business is one of the choices she had, though she experienced setbacks and some challenges, she strived hard and add more efforts to attain success though she did not impliedly or explicitly tell she has attained success in her business so far.

\subsection{Data Collection}

Exploring views, opinions, practices, beliefs, or motivations are just few of the activities or data that a research interview can extract from an informant. The most common form of data collection in a qualitative research is through interviews. In general, interviews, as one of the qualitative research methods, is the best methodology to deeply understand social problems compared to basic quantitative techniques such as the use of questionnaires. They are best for uncovering sensitive issues in the society because detailed insights are required especially for subject matters that are not commonly discussed in public caucus (Silverman, 2013).

However, Merriam (2009) did not suggest that this methodology must be the number one option of the researchers in the list, instead she articulated and clearly emphasized the significance of this process as it also frames the research procedures. Merriam also 
promoted the idea of carefully planning the data collection, development and completion of the process. King, Horrocks, and Brooks (2018) also posited that the principal purpose of interviews in qualitative inquiry is to comprehend a particular issue on the viewpoint of the participant. In addition. Babbie and Mouton (2011) described a qualitative interview as a communication between the researcher and the informant wherein the former carefully planned the data gathering activities. Further, the process of inquiry must not solely rely on a set of questions.

A week before the scheduled interview, we personally outlined a plan on how to carry out the formal interview. First, the researchers identified the informants based on the predefined inclusion and exclusion criteria (Patino \& Ferreira, 2018). In doing so, we asked someone to help us reach the five informants as she personally knew some of them. After meeting them personally, rapport with the informants was undertaken to establish connection and confidence.

Seidman (2013) generically described rapport as harmonious relationship, conformity, and getting along with each other and this is also a way of communicating empathy and appreciation without bias (Patton, 2015). Additionally, the researchers decided to get in touch with them before the actual interview since we want to observe the basic transactions of their "sari-sari" stores and how they established their name in the small community they belong to. In the course of our visit to them, we also had an opportunity to converse with the customers and even had a chance to cater them in the purchase transactions.

Moriarty (2011) explained that prior to the interview schedule, research participants must be informed about the details of the data collection and they must be assured that the principle of ethics is properly observed. This will allow them to draw their expectations about the interview and might be compelled to tell the truth. This is also emphasized as this element forms part of the informed consent process.

On the day of the scheduled interview, we began with a thorough and complete explanation about the interview process so with the purposes and objectives of the study. We began our formal interview with the generic question based on the interview guide. When asking questions, it is important that the researcher must begin with easy questions before proceeding to sensitive or difficult issue. This is to make sure that participants are at ease and readily confident to answer all the questions and obtain a rich data (Moriarty, 2011).

In the course of the face-to face interview, we also observed the demeanor of the participants. This is important as it was my way of validating truth in their answers. Another thing is, this gives us the opportunity to ask and clarify answers which are not exact and hypothetical. Swift and Tischler (2010) affirmed that face-to-face interviews manifest special meanings. The possibility to modify the questions is highly possible in order to get an interesting response. More so, Verlag (2013) ascertained that in-depthinterviews are semi-structured interview technique designed to allow the interviewer for a wide freedom to ask and the data that can be obtained is essentially rich. Through this 
data collection method, concepts, views, and perspectives are well preserved and series of arguments are conserved.

We also made sure that all the important points and views that were uttered by the informants were jotted down. When they tried to make a point, we allowed them freely and did not care to interfere nor interrupt as we wanted to make sure they are at a constant level of momentum especially if the question needs to recall their past experiences. The researchers attentively listened to their stories and assured that they have fully recounted their stories as women entrepreneurs. Interviewers must make sure that they have a neutral body movement during the interview and strategically use their silence. By this, informants can fully contemplate, respond and elaborate their viewpoints and opinions (Gill, Stewart, Treasure, \& Chadwick, 2008).

Also, Karnieli-Miller, Strier, and Pessach (2009) argued that during the data collection, the situation is purely in the hands of the interviewee as the informant is totally dependent on the knowledge and insights that the informant has to offer. Thus, most of our supporting question depends on their accounts and viewpoints were expounded within the subject matter of the discussion.

Before ending the formal interview, we asked the participants if there are other points that they want to exemplify. This is important so we can deal with the important issues within the context being studied and an opportunity to address some inquiries that were missed during the interview. We also extended our heartfelt gratitude for the opportunity to converse and for lending us their invaluable time. Gaponova (2017) clearly stated that after each interview, participants must be debriefed. More so, tape-recorded interviews should be transcribed in verbatim as it is a permanent documentation of everything that have been discussed. Field notes are also useful during and after the interview as the important concepts noted can help in the data analysis phase. Field notes is the best partner of the audio-taped interviews. This gives the researcher a clue when transcribing the data on the behaviors and conduct that the researcher exhibited during the in-depth interview. Field notes are usually done in small notebooks that plays important roles in the interpretation of the recorded interview and will serve as cue on situational elements upon doing the data analysis (Sutton \& Austin, 2015).

\subsection{Data Analysis}

In determining the themes and patterns that emerged in this research, a content analysis approach was employed. Content analysis has been defined by Leedy and Ormrod (2001) as a thorough and organized process of examining the content of the materials with the goal of identifying biases, themes, and patterns. This method of analysis was first used to analyze advertisements, articles, and even political speeches (Cho \& Lee, 2014). Currently, the fields of journalism, sociology, psychology, and business are widely using this technique (Aksan \& Baki, 2017). Content analysis involves two important processes. First, the researcher scrutinizes the material and categorize them in a frequency table labelled as characteristics or qualities. The second part, the researcher initiates the statistical analysis and present the results in quantitative format. 
HOLISTICA Vol 11, Issue 2, 2020, pp. 25-51

Content analysis emphasizes that number of times that a word, phrase, or a particular theme occurred. It is commonly used to evaluate social phenomenon thereby interpreting images and words from art, music, films, books, documents etc. (Mohajan, 2018). As such, open-ended questions are used during the interview if the researcher wish to use content analysis as a data analysis method (Hancock, Windridge, \& Ockleford, 2009). Case studies usually use content analysis to examine the communication of messages. For the past years, Hsieh and Shannon (2005) observed that this is a development of this approach. These researchers observed that coding classification comes directly from text, a theoretical perspective of the research must be established first as it will be used during the analysis of initial coding, and finally a cumulative analysis follows where counting categories heads the interpretation stage.

\subsection{Trustworthiness}

Trustworthiness in a qualitative inquiry is justified and assured when the process went through a thorough process. Trustworthiness means the worth of truth and/or transparency of the research findings. This element is important in assessing the practicality of the research findings (Cope, 2014). In a qualitative study, trustworthiness has four significant elements, these are: credibility, confirmability, dependability, and transferability. These four factors must be present and convincing enough as these are the foundations of a qualitative research design (Veal, 2011; Bryman, 2012; Loh, 2013).

To establish credibility in this undertaking, we made sure that the right informants who satisfied the inclusion criteria of this study were the ones involved. We ascertained first that the informants whom we are going to ask with the set of prepared questions are credible "sari-sari" store owners. Second, the researchers have done the member checking process through which we personally presented to them the transcriptions to validate that those were the exact answers that they have provided during our interview. Lastly, we also employed peer debriefing technique where we consulted at least two experts in the field about the findings of our research. The concept of credibility is manifested through peer debriefing, member checking, data triangulation and reflective journaling (Padgett, 2008).

To address confirmability, we strictly prevented our personal views and opinions about the subject matter on the course of the interview. More so, during the interview, we refrained ourselves from making unnecessary remarks or judgements on their answers as we wanted to promote neutrality and prevent bias answers. Another reason of doing this is for the "sari-sari" store owners to clearly and credibly paint a picture of their experience as women micro entrepreneurs in relation to failures and success. According to Connelly (2016) confirmability means the impartiality of the research findings that when replicated, results are relatively consistent.

To assure transferability, we made it sure that this study is based on an acceptable theoretical context and models of micro business and women entrepreneurship. Though Drury, Homewood, and Randall (2011) conclude that qualitative researches cannot possibly demonstrate a generalizable findings and conclusions, at the very least we have 
HOLISTICA Vol 11, Issue 2, 2020, pp. 25-51

clearly outlined, clarified and shed light about the success and failures of "sari-sari" business in the context of the developing nation.

In ensuring that dependability was observed in this paper, we ensured that the appropriate process and practices were strictly followed based on the methodology that we used. More so, we used an overlapping technique where we carefully documented and observed transparency on the method of analysis, data collected, and the research design. The procedures in the study were stated in detail, thus permitting future researchers to replicate the study and achieve similar results. More so, Connelly (2016) extrapolated that dependability is manifested by means of preserving the audit trails, field notes, memos, logs, and the peer debriefing process with peers. Process logs contain the full details of the whole study including interviews, observations, and plans.

\subsection{Ethical Consideration}

To ensure that the ethical consideration principle was considered in this research, we abide with the ethical guidelines provided by Mack (2005). Authors stated that respect for persons, beneficence, justice, confidentiality and consent are the components needed to guarantee ethics in research. Respect for persons acknowledges the independence of the respondents where their participation to the study is on voluntary basis. Under this element, the informed consent process was also taken into account. Prior to the proper interview, we personally asked their permission to be the informants of the study and after verbally assenting, we asked them to affix their signatures in the informed consent forms. In addition, we fully disclosed the full details, objectives, aims, purposes, and nature of the research and the opportunity to raise questions.

Beneficence on the other hand emphasizes the distribution of benefits, risks and problems across the population. It is important that the researcher has to maximize the benefits and minimize the potential risks that might occur in the study. To address this concept, we assigned pseudonyms to every participant and their personal circumstances remained protected. According to Australian Council for International Development (2017) beneficence signifies that the possible benefit to the informants or the community in general substantiates the harms that the research may cause to the participants. Thus, the research findings must be valuable to the informants and the whole community they are representing.

Lastly, justice. This principle is closely tied to equality. ACFID (2017) clearly outlined that that this tackles about the one who bears the benefits and the endures the burdens. To mitigate this, each sector mentioned in the study must have a fair share of societal contribution and recognition. In this study, we addressed this through a fair process of recruitment. We also made sure that participants were not personally exploited, rather, we promoted active participation treating all informants with the respect they deserve irrespective of social status, ethnicity, religion, culture, and personal abilities. Discrimination, marginalization, and any form of hostility were not tolerated in this study. 
HOLISTICA Vol 11, Issue 2, 2020, pp. 25-51

Ethical consideration is a fundamental segment of the research process. In conducting qualitative researches employing in-depth interview, the investigator must elucidate the goals and aims of the study to the informants, its processes, and even the methodology in analyzing and presenting the data. Individual differences should not be an issue during the interview so that participants will not hesitate to share their views and opinions outlined in the research (Graziano \& Raulin, 2010).

\section{Results and discussions}

\subsection{What are the success and failure stories of women micro entrepreneurs?}

Presented in Table 1 is the summarized themes regarding the stories of failures and success of "sari-sari" store owners. Among the essential themes that emerged in the first research questions are the following: new investments, enhanced family income, productive endeavor, entrepreneurial resourcefulness, business breakdown, and personal crisis.

Table 1 Major Themes and Core Ideas on Stories of Success and Failures of Women Micro Entrepreneurs

\begin{tabular}{|c|c|}
\hline Major Themes & Core Ideas \\
\hline \multicolumn{2}{|l|}{ Stories of Success } \\
\hline \multirow{5}{*}{ New Investments } & Invested the income in other business such as piggery \\
\hline & Purchased a piece of land from the profit \\
\hline & Acquired a tricycle; put up a boarding house \\
\hline & Sent 4 children through college; all now professionals \\
\hline & Supported kids' schooling \\
\hline \multirow{6}{*}{ Enhanced Family Income } & Supplemental income during hard times \\
\hline & Additional income helped family's financial needs \\
\hline & Augmented income of husband \\
\hline & Profits supported family expenses \\
\hline & Provided financial needs when husband had no work \\
\hline & Income served as additional source of income \\
\hline \multirow{6}{*}{ Productive Endeavor } & A lucrative pastime \\
\hline & Did not experience bankruptcy so far \\
\hline & Had plenty of customers \\
\hline & Business continued flourishing \\
\hline & "Sari-sari" store business was somehow profitable \\
\hline & Started with a loaned capital and now it is earning \\
\hline \multirow{6}{*}{$\begin{array}{l}\text { Entrepreneurial } \\
\text { Resourcefulness }\end{array}$} & Sold varied goods, so customers won't be seeking elsewhere \\
\hline & Customers' needs were all catered \\
\hline & Keeping the store open to attract more customers \\
\hline & Did not allow trials and failures to get in the way \\
\hline & Never stopped operation/close the store \\
\hline & It helped to be frugal and to use store goods sparingly \\
\hline
\end{tabular}


HOLISTICA Vol 11, Issue 2, 2020, pp. 25-51

\begin{tabular}{|c|c|}
\hline & Borrowed money to support business operation \\
\hline \multicolumn{2}{|l|}{ Stories of Failure } \\
\hline \multirow{8}{*}{ Business Breakdown } & Ventured into gold-buying business and lost/failed \\
\hline & Experienced loss and deficit \\
\hline & Customers were divided; income dived \\
\hline & Always infused capital; took a long time to earn \\
\hline & Items purchased were not disposed/sold \\
\hline & Seasonal customers \\
\hline & Used merchandize for personal consumption \\
\hline & Business started losing \\
\hline \multirow[t]{2}{*}{ Personal Crisis } & Health suffered; capital lost \\
\hline & Husband met an accident \\
\hline
\end{tabular}

\subsubsection{New Investments}

The ultimate driver of their success in the "sari-sari" store business is the chronic poverty in the Philippines. For average people, life in the countryside is not easy and most of the poverty-stricken communities and the largest population of poor families are in the rural towns. Under this theme women entrepreneurs narrated that their profit is reinvested in another line of business and it is continuously earning. Aside from that, the excess revenue from the "sari-sari" store business also made other endeavors possible such as sending their children to school and finally earn their degrees. Haque and Greig (2011) posited that women showed a more efficient way of responding to initiatives intended to nurture sectoral developments especially those who do not have enough knowledge in dealing with the formal sector. In addition, it appears that, ninety percent of women reinvest their income for family related welfares compared to men (Fortson, 2003). In the context of a developing world, research shows that household revenues handled and supervised by women greatly influence the education of their children for their survival (World Bank, 2011).

\subsubsection{Enhanced Family Income}

Back then, the role of women was simply to do household chores and take care of their children. Meanwhile, the husband goes to work as primary wage earner. However, as the years gone by, women are empowered and decided to work for the family and financial stability. For women who do not have access in the informal sector, engaging in a profitable economic activity is their way to contribute as additional income to their husband. Based on Acs, Amorós, Bosma, and Levie's (2009) findings, the involvement of women in any entrepreneurial activity is an indicator that self-employment is a strategy to avoid institutional and cultural restrictions with respect to the employment of women in the formal sector.

In relation to this, women also demonstrated a better entrepreneurial qualities and attributes in recognizing opportunities to provide income for their personal expenses and their respective families. In the same way, women engage in a business activity exclusively 
to make additional money. This is usually seen in households where the husband is the main source of income (Welter \& Smallbone, 2010).

\subsubsection{Productive endeavour}

Informants reported that entrepreneurship is such a productive venture. Engaging in a micro business like a "sari-sari" store gave them the opportunity to achieve growth, nourished their skills and increased productivity. Saleem (2017) emphasized that there are various determinants of business success. In most cases, economic related indicators involve survival and existence of the enterprise, sales volume, profit and the total assets acquired. For non-monetary success indicators, it includes productivity, personal achievement, growth and consumer satisfaction. For instance, in Kosovo, there are reforms in the country's policies in terms of economic development in which it primarily concentrated on mitigating the unemployment rates in the region and boost domestic productivity. Other important elements that it targeted to develop are infrastructure, chronic poverty, and business conditions (Haxhiu, 2015). While for Saudi Arabian women entrepreneurs, Sadi and Al-Ghazali (2012) revealed that self-achievement also appeared to be the most important motivating factor why these women engaged in an entrepreneurial activity. Alam, Jani, and Omar (2011) also suggested that women in developing nations were primarily motivated by achievement to do business and engage in lucrative ventures.

\subsubsection{Entrepreneurial Resourcefulness}

In a business environment where stiff competition prevails and limited resources are extremely scarce, entrepreneurial ability such as being resourceful can be a key to keep the business in transit to its goals. "Sari-sari" store owners attributed these traits to success which grew and developed throughout their entrepreneurial journey. Entrepreneurial resourcefulness relates to the capacity of the entrepreneur to control his behavior when confronted with problems or challenges (Powell \& Baker, 2011) and there were there competencies involved, affective, cognitive and psychomotor (Nandamuri, Gajulapally, \& Ch, 2012). During difficult times, these competencies can help the entrepreneurs in winning the game and entrepreneurial behavior is influenced by these competencies as Reuel Johnmark, Munene, and Balunywa (2016) argued that being resourceful is one factor that influences the business owner to likely succeed in business. Taking a closer look into the perspective of the Resource-Based View (RBV) theory by (Wernerfelt, 1984), it magnifies that tangible and intangible resources are the key for the excellent performance of the enterprise.

\subsubsection{Business Breakdown}

Due to the imperfect nature of human beings and the uncertainty of every situation, loss in business is inevitable and at times this will result to a cessation of business operation. Bunch of literatures provided various reasons of business failures and in this case, the common reasons why small enterprises such as "sari-sari" stores failed are usually personal and family related. For instance, The Experimentrepreneur almost lost her capital 
HOLISTICA Vol 11, Issue 2, 2020, pp. 25-51

investments as the goods in her store are consumed by the family without paying for it. Based on Cope's (2011) findings, failure would be a financial burden suffered by the entrepreneur when he/she encountered loss of sales or decline in income. When confronted with this issue, entrepreneurs tend to mitigate this problem by means of personal loans that takes years to pay. in case of failure, the entrepreneur will surely suffer from a substantial loss and financial failure (Arora \& Nandkumar, 2011).

\subsubsection{Personal Crisis}

Women entrepreneurs are also humans who can feel the bitter tastes of unavoidable situations. In fact, they have suffered more than the family members who actually experience physical and even emotional pains. Sometimes, the need to earn money and the obligation to look after their family members is extremely a tough and challenging task for women, however, they cannot escape from this reality as this is innately tied to their role as mothers. Personal situations directly affect business endeavors; this chain reaction is a consequence of the reality that women entrepreneurs are the only persons who are in control of two different undertakings. This finding is in consonance with Adjei and Denanyoh (2016) who described that familial responsibility is commonly a prime reason of failures among businesses managed by women entrepreneurs. Nursing their infants and taking care of their husbands were just few of the maternal responsibilities that women need to fulfill in their household and they have a problem of separating personal situations with the business endeavors, both appears to have an equal weight for them. Following Dhillon's (2017) study, he explained that more women are turning to entrepreneurship because of some traumatic circumstances and for economic reasons as well. Saurabh (2012) also observed that women micro enterprise owners meet a lot of problems in family, financial, marketing, and health related problems.

\subsection{How do failures framed them to achieve success in managing their "sari-sari" stores?}

Presented in Table 2 is the summarized themes regarding the stories of failures and success of "sari-sari" store owners. Among the essential themes that emerged in the first research questions are the following: new investments, enhanced family income, productive endeavor, entrepreneurial resourcefulness, business breakdown, and personal crisis.

Table 2 Major Themes and Core Ideas on How Failures Frame Women Micro Entrepreneurs to Achieve Success in Managing Their Sari-Sari

\begin{tabular}{|l|l|}
\hline Major Themes & \multicolumn{1}{c|}{ Core Ideas } \\
\hline \multirow{4}{*}{ Determination } & Did not let problems preoccupy mind; try not to get affected \\
\cline { 2 - 2 } & $\begin{array}{l}\text { Not letting failures get the better of you; not minding the } \\
\text { difficulties }\end{array}$ \\
\cline { 2 - 2 } & Be confident that trials will be overcome; don't be discouraged \\
\cline { 2 - 2 } & Never think of quitting and giving up, be bent on moving on \\
\cline { 2 - 2 } & Continue to be happy; never mind the trials \\
\hline & Offered all problems to God; sought refuge in Him \\
\hline
\end{tabular}


HOLISTICA Vol 11, Issue 2, 2020, pp. 25-51

\begin{tabular}{|c|c|}
\hline \multirow{4}{*}{ Spirituality } & Faith in God and trusting \& believing that God will help \\
\hline & Trusted the Lord and prayed \\
\hline & Trust that one will definitely surpass all troubles and problems \\
\hline & Believed that trials don't last \\
\hline \multirow{6}{*}{ Diligence and Cleverness } & Double the effort; work even harder \\
\hline & Just keep working hard; don't ever stop \\
\hline & Organized the records, especially on loans, credit and sales. \\
\hline & Maintained good relationship with customers \\
\hline & Borrowed money for additional capital \\
\hline & Disallow customers take goods on credit to minimize losses \\
\hline \multirow{5}{*}{$\begin{array}{l}\text { Optimism and } \\
\text { Confidence }\end{array}$} & Don't entertain and give in to negativity; just chill, take it easy \\
\hline & Stay positive; believe that business would grow and be profitable \\
\hline & Just go on while still alive \\
\hline & Don't let problems kill you or else you'll be laughed at \\
\hline & Lifting self up when times are really bad \\
\hline
\end{tabular}

\subsubsection{Determination}

Business failures connote a negative concept for some and even dictionaries define failures as fiascos in business operations, but these micro entrepreneurs described failures in other way. For them, it framed them to strive better and serve as a learning avenue. Failures allowed them to develop these attributes that partly helped boost themselves to attain the goals of their small enterprise. Hossain, Naser, Zaman, and Nuseibeh (2009) posited that self-determination is the pedestal of which entrepreneurial behavior stands. Self-determination serves as a fundamental agent in the life of an entrepreneur and an influencer on the quality of decision that he has to take without the interference of external factors. A person who consistently manifested a self-determined behavior is tagged as a determined individual which is a natural character (Shogren et al., 2015). Under this perspective, an individual who passionately and enthusiastically engage in an endeavor because he/she assigned a value to it. Hence, determined entrepreneurs ventured into business because they find it valuable and is beneficial to them in many ways. Self-determination is a component of entrepreneurial behavior thereby providing a meaning to the person's behavioral expression and is exhibited by the degree of confidence in performing entrepreneurial activities (Deci \& Ryan, 2011).

\subsubsection{Spiritualty}

Filipinos are known for their undying love and belief in the Almighty Father. God is the center of every Filipino household and almost all Filipino, regardless of the class or tribe recognized His power, unconditional love, unending mercy. Perhaps, this is the reason why women entrepreneurs find refuge in him. This is one thing that is worth admiring among these women entrepreneurs. Din's (2007) findings supports this theme by theorizing that faith entails confidence from the heart, spoken through one's tongue and seen in the person's actions. Faith is also the foundation of our relationship with the Lord 
or Allah for Muslims. Counting on studies about the elite entrepreneurs by Lindsay and Smith (2010) and the research on the growing number of entrepreneurs who associated their endeavors with their faith (Lambert III \& Lambert, 2009) has indeed proven the relationship of faith and work. In relation to that, American Entrepreneurs also found religion as a special plus factor in their business (Dougherty, Neubert, Griebel, \& Park, 2013). Counting on studies about the elite entrepreneurs by Lindsay and Smith (2010) and the research on the growing number of entrepreneurs who associated their endeavors with their faith (Lambert III \& Lambert, 2009) has indeed proven the relationship of faith and work.

\subsubsection{Diligence and Cleverness}

Being diligent is a positive Filipino trait, not just for entrepreneurs, but for breadwinners as well. Housewives happen to be family breadwinners when the husbands are not capable of supporting the family due to illness, accidents or even left the family for good. In case of women micro business owners, the problems, trials, and challenges that they have encountered prompted them to exert more effort in their business and become clever at the same time. Women do a lot a business and self-evaluation and based on assessment, they are qualified to manage an enterprise as they are also quite satisfied with their economic and social status (Deng, Wang, \& Alon, 2010). In the past, women are confronted with social difficulties due to gender discrimination but many of them managed to be successful in their field. They made their own name and gather wealth through entrepreneurial competence (Sari \& Sari, 2018), diligence, and hard work (Attar \& Jawale, 2012).

\subsubsection{Optimism and Confidence}

The failures that these women entrepreneurs faced did not negatively affect the best in them. Instead, it fostered positivity and built strong confidence skills. Guided with their unstoppable faith, they were confident enough that they can cope with the challenges as they saw it as temporary circumstances. They do not allow negativity to affect their entrepreneurial endeavors as it will only worsen the situation. Indeed, the optimism and degree of confidence that these women entrepreneurs possessed is amazing and extraordinary. The basic explanation why women entrepreneurs still persist even when their income is extremely low or the situation is getting riskier is because of overconfidence and positivity (Benz, 2009). Optimism and confidence proved to help realize success of the enterprise. Storey (2011) found out that small and newly established enterprises' success can be best understood if entrepreneurial efforts are mixed with positivity. Scholarly discussions also showed that entrepreneurs have a high level of optimism and confidence (Hmieleski \& Baron, 2009). For individuals who just started putting up their micro enterprise, they have a problem of which particular foundation will they be able to base their goal of attaining success and the power of positivity can help solve this issue (Dawson, de Meza, Henley, \& Arabsheibani, 2014). Consistent to that, people who possess an overwhelming amount of optimism are assured to achieve successful results (Hmieleski \& Baron, 2009). Therefore, optimism is an integral part of 
HOLISTICA Vol 11, Issue 2, 2020, pp. 25-51

the entrepreneurial process (Adomako, Danso, Uddin, \& Damoah, 2016). Other literatures also suggest that optimism motivated determination (Solberg Nes, Evans, \& Segerstrom 2009).

\subsection{What significant insights can the participants share to their peers?}

Given the number of years in operating or running their "sari-sari" store Women entrepreneurs have shared a lot about the successful and the worst stories that they had. Of course, these stories produced some meaningful lessons for these women of which they can practically apply in continuing to chase success and excellence in managing their micro-enterprise. There are three essential themes in this research question: Be business oriented, employ will power, and develop people skills as presented in the following table.

Table 3 Major Themes and Core Ideas on Significant Insights that Participants Can Share to Peers

\begin{tabular}{|l|l|}
\hline Major Themes & \\
\hline \multirow{5}{*}{ Be Business Oriented } & Know the whole process in working out business \\
\cline { 2 - 3 } & Manage the business properly no matter how small \\
\cline { 2 - 3 } & Skill and ability will see business through \\
\cline { 2 - 3 } & Develop business ability to stay afloat in business \\
\cline { 2 - 3 } & Staying focused helped make the business a success \\
\cline { 2 - 3 } & Be wise in dealing with creditors \\
\cline { 2 - 3 } & Know how to deal with competition \\
\cline { 2 - 3 } & Proper documentation and recording are important \\
\hline & Work hard and persevere; don't be easily discouraged \\
\cline { 2 - 3 } & Be kind but don't let others abuse your kindness \\
\cline { 2 - 3 } & Never give up; never surrender \\
\cline { 2 - 3 } & Because of persistence and perseverance, business became a success \\
\cline { 2 - 3 } & Even when you feel like you're failing, just continue and move on \\
\cline { 2 - 3 } & Just go on even if sometimes profit is hard to come by \\
\cline { 2 - 3 } & In business, you don't always stay on top; sometimes you're down \\
\hline & Entertain customers pleasantly \\
\cline { 2 - 3 } & One should have good relationship with customers \\
\cline { 2 - 3 } & Be patient and understanding with customers and creditors \\
\cline { 2 - 3 } & With customers, patience is a must \\
\cline { 2 - 3 } & Win the trust of people \\
\hline & Keep a harmonious relationship with customers; be friendly \\
\cline { 2 - 3 } & Analyze what customer needs \\
\hline
\end{tabular}

\subsubsection{Being Business Oriented}

Women micro entrepreneurs emphasized the need to acquire a significant amount of knowledge in running the "sari-sari" store business. This entails substantial details about the product lines or assortments that the store must offer, studying the target customers, credit terms and agreements, competition, basic bookkeeping, and the entrepreneur's knowledge on the government and regulatory requirements of the business. One 
common area that all micro-entrepreneurs must develop their knowledge more is the taxation part. This is also due to the shift from the original and newly introduced taxation schemes. Another is the new technologies and processes which they need to adopt these developments since consumers are going smart. terms of knowledge in managing the enterprise, BarNir (2012) argued by positing that education should not be disregarded as it plays a significant role of achieving success. Entrepreneurs who finish a degree are more likely to realize better business results. Women who also have enough experience in the field or has worked in companies with better performances increase their knowledge in doing business (Fairlie \& Robb, 2009). Additionally, it is factual that women have achieved a considerable amount of success in running businesses and their personality characteristics and personal knowledge greatly helped them in various ways (Klyver \& Grant, 2010). Skills such as marketing, product development, quality control and industryrelated are also required (Mamabolo, Kerrin, \& Kele, 2017).

\subsubsection{Employ Will Power}

Motivational factors and other significant entrepreneurial traits are nothing without will power. This is something that pushes confidence and perseverance to stay in track while fighting odds in the business environment of women entrepreneurs. A strong will power will ignite the confidence to push through things and achieve successful results. Too often, entrepreneurs feel the squeezing thorns of hardships and they are emotionally weak, but if one has strong will power, he/she is not easily swayed by any emotional weakness and confidence will start to boost its way to find viable solutions.

In fact, Mboko and Smith-Hunter (2010) support this by conceiving that women entrepreneurs have challenged the societal notion that they are weak, pure housewives and not capable of managing an enterprise. Actually, women entrepreneurs have dealt with this kind of scenario by proving their worth and value in economic and social developments and fought their way through. When this situation arises, they immediately deal with it one at a time. Xavier, Ahmad, Nor, \& Yusof (2012) showed the entrepreneurial characteristics of women entrepreneurs. Their passion to engage in business is influenced by confidence, courage and strong will power. These were considered as their strongest skills. Also, in pursuing their dreams, they fought shortcomings or obstacles by their innate strength and power (Xavier et al., 2012). Yimamu (2018) suggested that without strong will and power to overcome challenges, success is clearly impossible. No matter how long the exposure or experience in the field, the strength of the motivation to continue and being resolute is still the best weapon above all.

\subsubsection{Develop People Skills}

Longevity of the business operation is basically the aim of every entrepreneur in the industry. To achieve this, "sari-sari" store entrepreneurs unanimously explained the relevance of keeping in touch with their customers every now and then. Due to the stiff competition of "sari-sari" store business in the Philippines, entrepreneurs discovered and develop this so called "suki" system where they have permanent patrons. Winning permanent customers is a difficult task and necessitates a high degree of genuine and true 
relationship. Taking care of customers is a silent marketing strategy that businessmen fail to recognize. Communication skill, people skills, relationship skills, and cultural sensitivity are the best skills under social aspect. In terms of personal trait, the category involves hard work and self-motivation (Mamabolo et al., 2017). In order for small business to gain a competitive edge in the industry, soft management skills such as interpersonal abilities must be implemented. Through interpersonal skills, achieving success is possible. This is also required as human capital is now increasingly important in all the aspects of business activities. More so, the constant change of the necessary skills in the industry requires an updated strategy to implement this strategy (Holmberg-Wright \& Hribar, 2016). EvansRaoul (2013) also argued that an excellent entrepreneur can be assessed through the quality of their personal, interpersonal skills and their outputs. The competitive advantage of the business cannot be fully established if strong communication is disregarded which happens to be part of people skills (Ameen, Hameed, Bashir, Bashir, \& Amin, 2015). Entrepreneurs must also be keen in knowing the people skills that they possess and determine which is lacking (Unger, Rauch, Frese, \& Rosenbusch, 2009). The best way to win the game in any business battle is to invest more on the soft skills rather than focusing more on the infrastructure, products, or the physical element of the enterprise.

\section{Implication for practice}

Women micro entrepreneurs have their own way of interpreting, defining, and quantifying business success as well as failures in their "sari-sari" store business or their small enterprise. For instance, there were women who focused on the soft skills such as resourcefulness and productivity that they have acquired in the course of doing business and for them, this is a kind of success that they will not forget in their life as micro entrepreneurs. Looking into the practical side, financial freedom, earning capacity, and new investments are just few of the defining moments of business success. It is also worth noting that at some point in their life as micro-entrepreneurs, they are economically assured as they considered their entrepreneurial activity as a productive endeavor.

Accordingly, Cabrera and Mauricio (2017) pointed out that entrepreneurial success in the context of small enterprises is a satisfactory result of an attempt to engage in an entrepreneurial endeavor. Its measurement varies from one entrepreneur to the other and their defining factors may range from quantitative elements such as economic or financial gains or qualitative in the form of balanced life or sense of achievement. In the same context, Weber (2014) noted that success is not solely determined by a common indicator rather it depended on the subjective judgements of the women entrepreneur. Studies also showed that business success is directly linked to economic independence, proactive personality, and the ability to handle unfavorable situations and risks (Rauch \& Frese, 2007).

On the stories of failures, women entrepreneurs do not really dwell on these factors/aspects and it is interesting to know that they somehow do not mind the challenges. However, there were practical ways which may be considered to address the 
issues relating to failures experienced by women entrepreneurs. Authorities may put up business incubator facilities. Issues on lack of managerial, technical and financial difficulties might be addressed through business incubation. As things will be done on trial and error basis, this facility is the perfect chance for entrepreneurs to magnify their knowledge and sporadically observe their progress and growth. Xu (2009) highlighted that the primary purpose of establishing a business incubator facility is for development. In effect, the main target of this facility is to minimize failures and produce successful businesses that may allow independence and financial viability.

Second, it can be noted that there were traits and entrepreneurial characteristics that were developed by women such as being determined, diligent, optimistic, and a strong devotion to the almighty Father. These entrepreneurial traits and competencies were developed during their entrepreneurial journey and somehow framed by the challenges and failure that they have encountered. Based on the study done by Singh (2012), women entrepreneurs may encounter problems in their entrepreneurial journey and these challenges are going problematic due to the twofold responsibilities of women at home, however, it is worth considering that these women entrepreneurs fearlessly faced the risks and challenges using the available resources in their environment and reap the compensations of their efforts (International Labor Organization, 2015). Women are also capable of starting or creating a high profit generating business activity as they have the power to envision, have a sound mind setting and skillful in scaling up their enterprise (Timmons \& Spinelli, 2009).

Third, women entrepreneurs provided some significant insights that they want to share with other women entrepreneurs. It can be gleaned that having a sound business orientation, possessing a strong will power, and developing people skills were just few physiognomies that make a small venture a successful one. Theoretically, Schumpeter (1934) noted entrepreneurial orientation is a practice by which entrepreneurs determine and exploit viable opportunities, processes, and products. More so, having a good entrepreneurial orientation leads to new business opportunities (Wiklund \& Shepherd, 2003; Walter, Auer, and Ritter, 2006). This further infers that possessing these characteristics is not only good for themselves as women as acknowledged by some but as entrepreneurs who largely contribute to the overall success of their business, family and society at large.

Finally, long-term goals may be outlined and the idea that venturing into micro business is purely confined with the compelling reason to support the family's basic needs, additional income to the household, or just a part time job. Although these factors may be considered as successful motivators, let us not forget that we also need to build a sustainable business built on a strong vision and purpose within the sphere of a friendly and favorable business environment. Strong focus on developing a competitive Filipino enterprise managed by the mixture of our indigenous and acquired talents through which financial freedom, education, and entrepreneurial orientation is possible. Success in small business is demonstrated by the degree of the changes on the entrepreneurial attributes, qualities, behavior, and orientation of women micro entrepreneurs. 


\section{Implication For Future Research}

Given the limitations of this research, we would like to highlight two important path for future studies. First, it is noteworthy to study the effects of the implementation of RA 10963 otherwise known as TRAIN law on the operation of "sari-sari" stores. It cannot be denied that there were associated costs brought by the implementation of TRAIN Law on the operation and ability of micro businesses to obtain the desired revenue or profit. For instance, the increasing taxes imposed on a bottle of a soft drink or a pack of a local cigarette brand may discourage consumers to reduce consumption or even quit buying these goods for some economic reasons. This scenario may directly affect the revenue of the enterprise as the sales of such items may decrease.

Second, future researches may also look into the accounting method/strategy employed by "sari-sari" store owners especially on determining the actual value of their enterprise. Numerical literacy is one of the greatest issues that women entrepreneurs are in trouble with. Basic valuation of their assets, payment of wages, and inventory control is interesting to study. This is somehow related to this research as one indicator of success or failure in business is by quantifying the assets of the enterprise. More so, future studies may empirically or theoretically measure how entrepreneurial policy measures, training and programs, level of education, and knowledge improves entrepreneurial identity of women micro entrepreneurs.

\section{Concluding statement}

Enterprises owned and managed by women entrepreneurs have helped their families bridge the gap between poverty and comfortable life. Indeed, venturing into business maximizes the innate talents in them, explore market opportunities, as well as provide the necessities for the family. There may be stories of failures and crises in their entrepreneurial journey but stories of success and the special privileges that they have enjoyed outweighed them all.

Based on their stories, failures framed them to have more faith in God, become diligent and clever, and see life in the sphere of optimism. It is worth appreciating that instead of giving up to failures, challenges, and difficulties, they stand still and looked at their entrepreneurial journey in a brighter perspective. For years, they have developed the traits and attributes that cannot be bought by a tile of gold nor a kilo of silver. This is a product of an incredible and laudable strength of women whom were once considered as weak individuals

Finally, venturing in business is more than just earning money. It also means earning confidence to move forward, making a desirable amount of strong will power, and establishing a long-lasting relationship with customers. Women micro entrepreneurs recognize the value of creating a strong foundation of business success- real and warmth connection between the seller and the buyer. 


\section{References}

Acs, Z. J., Amorós, J. E., Bosma, N. S., \& Levie, J. (2009). From entrepreneurship to economic development: Celebrating ten years of Global Entrepreneurship Monitor. Frontiers of Entrepreneurship Research, 29(16), 1.

Adjei, K., \& Denanyoh, R. (2016). Micro business failure among women entrepreneurs in Ghana: A study of Sunyani and Techiman municipalities of the Brong Ahafo Region. International Journal of Economics, Commerce, and Management, 4, 1050-1061.

Adomako, S., Danso, A., Uddin, M., \& Damoah, J. O. (2016). Entrepreneurs' optimism, cognitive style and persistence. International Journal of Entrepreneurial Behavior \& Research, 22(1), 84-108.

Alam, S. S., Jani, M. F. M., \& Omar, N. A. (2011). An empirical study of success factors of women entrepreneurs in southern region in Malaysia. International Journal of Economics and Finance, 3(2), 166.

Ameen, Z., Hameed, T., Bashir, H. R., Bashir, H. F., \& Amin, H. A. R. (2015). Integrating strategic management actions and interpersonal skills in entrepreneurship to create Competitive advantage. American Journal of Marketing Research, 1(3), 189-192.

Aksan, E., \& Baki, A. (2017). Content analysis of curriculum-related studies in Turkey between 2000 and 2014. Educational Sciences: Theory \& Practice, 17, 877-904.

Arora, A., \& Nandkumar, A. (2011). Cash-out or flameout! Opportunity cost and entrepreneurial strategy: Theory and evidence from the information security industry. Management Science, 57, 1844-1860.

Attar, M. R. H., \& Jawale, S. R. (2012). Women entrepreneurs in India-present Scenario. Retrieved from http://www.nevillewadia.com/images/Cronicle2012/Mr.-Riyazkhan-H.-Attar12.pdf

Australian Council for International Development. (2017). Principles and guideline for ethical research and evolution and development. Retrieved from https://acfid.asn.au/sites/site.acfid/files/resource_document/ACFID_RDI\%20Principles\%2 Oand\%20Guidelines\%20for\%20ethical\%20research12-07-2017.pdf

[Babbie, E., \& Mouton, J. (2011). The practice of social research. Oxford University Press: Cape Town.

BarNir, A. (2012). Starting technologically innovative ventures: Reasons, human capital, and gender. Management Decision, 50, 399-419.

Benz, M. (2009). Entrepreneurship as a non-profit-seeking activity. International Entrepreneurship and Management Journal, 5(1), 23-44.

Bryman, A. (2012). Social research methods. Oxford: Oxford University Press.

Cabrera, E. M., \& Mauricio, D. (2017). Factors affecting the success of women's entrepreneurship: A review of literature. International Journal of Gender and Entrepreneurship, 9(1), 31-65.

Cho, J. Y., \& Lee, E. H. (2014). Reducing confusion about grounded theory and qualitative content analysis: Similarities and differences. The Qualitative Report, 19(32), 1-20.

Connelly, L. M. (2016). Trustworthiness in qualitative research. Medsurg Nursing, 25(6), 435-437.

Cope, J. (2011). Entrepreneurial learning from failure: An interpretative phenomenological analysis. Journal of Business Venturing, 26, 604-623.

Cope, D. G. (2014). Methods and meanings: Credibility and trustworthiness of qualitative research. Oncology Nursing Forum, 41(1), 8991.

Creswell, J. W. (2013). Research design: Qualitative, quantitative, and mixed methods approaches. Thousand Oaks, CA: Sage. 
Crouch, M., \& McKenzie, M. (2006). The logic of small samples in interview-based qualitative research. Social Science Information, 45(4), 483-499.

Cronin, C. (2014). Using case study research as a rigorous form of inquiry. Nurse Researcher, 21(5).

Dawson, C., de Meza, D., Henley, A., \& Arabsheibani, G. R. (2014). Entrepreneurship: Cause and consequence of financial optimism. Journal of Economics \& Management Strategy, 23(4), 717-742.

Deci, E. L., \& Ryan, R. M. (2011). Self-determination theory. Handbook of Theories of Social Psychology, 1(2), 416-433.

Deng, S., Wang, X., \& Alon, I. (2010). Framework for female entrepreneurship in China. International Journal of Business and Emerging Markets, 3(1), 3-20.

Dhillon, M. (2017). Challenges faced by women entrepreneur in India. International Journal in Multidisciplinary and Academic Research, 6(4).

Din, H. (2007). Islam: Effective referral of good manners. Malaysia: PTS Litera Utama.

Dougherty, D. D, Neubert, M., Griebel, J., \& Park, J. (2013). A religious profile of American entrepreneurs. Journal for the Scientific Study of Religion, 52,104-109.

Drury, R., Homewood, K., \& Randall, S. (2011). Less is more: the potential of qualitative approaches in conservation research. Animal Conservation, 14(1), 18-24.

Evans-Raoul, K. (2013). Soft skills: crucial to weathering an economic storm. Retrieved from http://citeseerx.ist.psu.edu/viewdoc/download ?doi=10.1.1.526.1774\&rep=rep1\&type $=p d f$

Fairlie, R. W., \& Robb, A. M. (2009). Gender differences in business performance: Evidence from the characteristics of business owners survey. Small Business Economics, 33(4), 375.

Figueroa, D. S. (2018). Cases of micro enterprises on the incentives and benefits of the barangay micro business enterprises act of 2002. Review of Integrated Business and Economics Research, 7(2).

Fortson, C. (2003). Women's rights vital for developing world. Retrieved from http://gulfnews.com/news/ gulf/uae/employment/nepal-to-ban-under-30-maids-fromworking-ingulf-1.1061376

Gaponova, M. (2017). Analysis of ICT system in the delivery health care services: Case of Kalevala Hospital. $\quad$ Retrieved from https://www.theseus.fi/bitstream/handle/10024/123038/Gaponova_Maria_Thesis.pdf?se quence=1\&isAllowed $=y$

Gibbert, M., \& Ruigrok, W. (2010). The "what"and "how" of case study rigor: Three strategies based on published work. Organizational Research Methods, 13(4), 710-737.

Gill, P., Stewart, K., Treasure, E., \& Chadwick, B. (2008). Methods of data collection in qualitative research: Interviews and focus groups. British Dental Journal, 204(6), 291.

Gillis, L. (2015). The consequences of failure in SMEs: A case study on the horticulture sector (Doctoral Dissertation) Ghent University.

Graebner, M. E., Martin, J. A., \& Roundy, P. T. (2012). Qualitative data: Cooking without a recipe. Strategic Organization, 10(3), 276-284.

Graziano, A., \& Raulin, M. (2010). Research Method: A process of inquiry. Cambridge: Cambridge University Press.

Hancock, B., Windridge, K., \& Ockleford, E. (2009). An introduction to qualitative research. Retrieved from http://www.rds-eastmid-lands.org.uk/resources/cat_view/13-resourcepacks.html

Haque, T., \& Greig, F. (2011). Increasing the participation of women entrepreneurs in the Solomon Islands aid economy. Retrieved from 
http://documents.worldbank.org/curated/en/894351468112756106/pdf/589180WPOSIO Wo10Box353823B01PUBLIC1.pdf

Haxhiu, E. (2015). The factors affecting success and performance of women entrepreneurs in Kosovo (master's thesis). University of Ljubljana.

Hmieleski, K. M and Baron, R. A. (2009). “Entrepreneurs' optimism and new venture performance: A social cognitive perspective". Academy of Management Journal, 52(3),473-488.

Holmberg-Wright, K., \& Hribar, T. (2016). Soft skills-the missing piece for entrepreneurs to grow a business. American Journal of Management, 16(1), 11.

Houghton, C., Casey, D., Shaw, D., \& Murphy, K. (2013). Rigour in qualitative case-study research. Nurse Researcher, 20(4).

Hossain, A., Naser, K., Zaman, A., \& Nuseibeh, R. (2009). Factors influencing women business development in the developing countries: Evidence from Bangladesh. International Journal of Organizational Analysis, 17(3), 202-224.

Hsieh, H. F., \& Shannon, S. E. (2005). Three approaches to qualitative content analysis. Qualitative Health Research, 15(9), 1277-1288.

International Labor Organization (2015). Jobs, gender and small enterprises in Bangladesh. Retrieved from http://www.cartierwomensinitiative.com/docs/ILO_Bangladesh.pdf

Jenkins, A. S., Wiklund, J., \& Brundin, E. (2014). Individual responses to firm failure: Appraisals, grief, and the influence of prior failure experience. Journal of Business Venturing, 29, 17-33.

Judama, S. K. (2013). Assessment of factors limiting small and medium enterprises growth in Zanzibar: A case of Zanzibar west district (Doctoral dissertation) Mzumbe University.

Karnieli-Miller, O., Strier, R., \& Pessach, L. (2009). Power relations in qualitative research. Qualitative Health Research, 19(2), 279-289.

King, N., Horrocks, C., \& Brooks, J. (2018). Interviews in qualitative research. Thousand, Oaks: SAGE Publications Limited.

Klyver K., \& Grant S. (2010). Gender differences in entrepreneurial networking and participation. International Journal of Gender and Entrepreneurship, 2(3), 213-227.

Lafond, D. (2014). MSMEs, key drivers to an inclusive growth in the emerging countries: A focus on financial services and agriculture in the Philippines. Retrieved from https://www.backbone.eu.com/wp-content/uploads/2017/03/InclusiveGrowthEmergingCountries-2014.pdf

Lambert III, L., \& Lambert, L. (2009). Spirituality, Inc: Religion in the American Workplace. New York: NYU Press.

Lindsay, D. M., \& Smith, B. C. (2010). Accounting by faith: The negotiated logic of elite evangelicals' workplace decision-making. Journal of the American Academy of Religion, 78(3), 721-749.

Leedy, P., \& Ormrod, J. (2001). Practical research: Planning and design (7th ed.). Upper Saddle River, NJ: Merrill Prentice Hall and Thousand Oaks: SAGE Publications.

Loh, J. (2013). Inquiry into issues of trustworthiness and quality in narrative studies: A Perspective. The Qualitative Report, 18 (65), 1-15.

Mack, N. (2005). Qualitative research methods: A data collector's field guide. Retrieved from http://repository.umpwr.ac.id:8080/bitstream/handle/123456789/3721/Qualitative\%20R esearch\%20Methods_Mack\%20et\%20al_05.pdf?sequence $=1$

Mamabolo, M. A., Kerrin, M., \& Kele, T. (2017). Entrepreneurship management skills requirements in an emerging economy: A South African outlook. The Southern African Journal of Entrepreneurship and Small Business Management, 9(1), 1-10.

Mathias, B. D., Williams, D. W., \& Smith, A. R. (2015). Entrepreneurial inception: The role of imprinting in entrepreneurial action. Journal of Business Venturing, 30,11-28. 
Mboko, S., \& Smith-Hunter, A. (2010). Zimbabwe women business owners: Survival strategies and implications for growth. Journal of Applied Business \& Economics, 11(2).

McMahon, R. G. (1998). Stage models of SME growth reconsidered. Small Enterprise Research, 6(2), 20-35.

Merriam, S. B. (2009). Qualitative research: A guide to design and implementation (2nd ed.). San Francisco, CA: Jossey-Bass.

Mohajan, H. K. (2018). Qualitative research methodology in social sciences and related subjects. Journal of Economic Development, Environment and People, 7(1), 23-48.

Moriarty, J. (2011). Qualitative methods overview. Retrieved from http://eprints.Ise.ac.uk/41199/

Munoz, J. M., Raven, P. V., \& Welsh, D. H. (2005). An exploratory study of retail servicenmanagement in the Philippines. Retrieved from https://www.researchgate.net/profile/Peter_Raven3/publication/228822901_AN_EXPLOR ATORY_STUDY_OF_RETAIL_SERVICE_MANAGEMENT_IN_THE_PHILIPPINES/links/Oc96051 d58a74ef3cf000000.pdf

Nandamuri, P. P., Gajulapally, R. K., \& Ch, G. (2012). A strategic analysis of entrepreneurial orientation of management graduates. IUP Journal of Business Strategy, 9(4), 7.

Padgett, D. K. (2008). Qualitative methods in social work research. Thousand Oaks, California, USA: SAGE.

Patino, C. M., \& Ferreira, J. C. (2018). Inclusion and exclusion criteria in research studies: definitions and why they matter. Brazilian Journal of Pulmonology, 44(2), 84-84.

Patton, M. Q. (2015). Qualitative researcher and evaluation methods: Integrating theory and practice, (4th ed.). London: SAGE.

Phillipson, J., Bennett, K., Lowe, P., \& Raley, M. (2004). Adaptive responses and asset strategies: The experience of rural micro-firms and foot and mouth disease. Journal of Rural Studies, 20, 227-243. https://doi.org/10.1016/j.jrurstud.2003.08.006

Powell, E. E., \& Baker, T. (2011). Beyond making do: Toward a theory of entrepreneurial resourcefulness. Frontiers of Entrepreneurship Research, 31(12), 2.

Rauch, A., \& Frese, M. (2007). Let's put the person back into entrepreneurship research: A metaanalysis on the relationship between business owners' personality traits, business creation, and success. European Journal of Work and Organizational Psychology, 16(4), 353-383.

Reuel Johnmark, D., Munene, J. C., \& Balunywa, W. (2016). Robustness of personal initiative in moderating entrepreneurial intentions and actions of disabled students. Cogent Business \& Management, 3(1), 1169575.

Sadi, M. A., \& Al-Ghazali, B. M. (2012). The dynamics of entrepreneurial motivation among women: A comparative study of businesswomen in Saudi Arabia and Bahrain. New York, NY: Springer.

Saleem, M. A. (2017). The impact of socio-economic factors on small business success. GeografiaMalaysian Journal of Society and Space, 8(1).

Sari, P. A., \& Sari, W. P. (2018). The Model of Firm Performance Improvement through Entrepreneurial Competence. HOLISTICA-Journal of Business and Public Administration, 9(3), 55-70.

Saurabh, S. (2012). Issues and challenges faced by women entrepreneurs and their training needs. SHIV SHAKTI International Journal of Multidisciplinary and Academic Research (SSIJMAR), 1(2), 1-8.

Schumpeter, J. A. (1934). The theory of economic development. Public Opinion Quarterly, 58, 358480. 
HOLISTICA Vol 11, Issue 2, 2020, pp. 25-51

Seidman, I. (2013). Interviewing as qualitative research: A guide for researchers in education and the social sciences, (4th ed.). New York: Teachers College Press.

Shogren, K. A., Wehmeyer, M. L., Palmer, S. B., Forber-Pratt, A. J., Little, T. J., \& Lopez, S. (2015). Causal agency theory: Reconceptualizing a functional model of selfdetermination. Education and Training in Autism and Developmental Disabilities, 251-263.

Silverman, D. (2013). Doing qualitative research: A practical handbook. Thousand Oaks, CA: SAGE Publications Limited.

Singh, R. (2012). Women entrepreneurship issues, challenges and empowerment through self-help groups: An overview of Himachal Pradesh. International Journal of Democratic and Development Studies, 1(1) 45-58.

Solberg Nes, L., Evans, D. R., \& Segerstrom, S. C. (2009). Optimism and college retention: Mediation by motivation, performance, and adjustment. Journal of Applied Social Psychology, 39(8), 1887-1912.

Storey, D. J. (2011). Optimism and chance: The elephants in the entrepreneurship room. International Small Business Journal, 29(4),303-321.

Sutton, J., \& Austin, Z. (2015). Qualitative research: data collection, analysis, and management. The Canadian Journal of Hospital Pharmacy, 68(3), 226.

Swift, J. A., \& Tischler, V. (2010). Qualitative research in nutrition and dietetics: getting started. Journal of Human Nutrition and Dietetics, 23(6), 559-566.

Timmons, J., \& Spinelli, S. (2009). New venture creation, entrepreneurship for the 21st Century. NY, USA: McGraw-Hill Higher Education.

Ucbasaran, D., Westhead, P., Wright, M. and Flores, M. (2010), "The nature of entrepreneurial experience, business failure and comparative optimism", Journal of Business Venturing, 25(6), 541-555.

Unger, J. M., Rauch, A., Frese, M., \& Rosenbusch, N. (2009). Human capital and entrepreneurial success: A meta-analytical review. Journal of Business Venturing, 26, 341-358.

Vannoni, M. (2015). What are case studies good for? nesting comparative case study research into the lakatosian research program. Cross-Cultural Research, 49(4), 331-357.

Veal, A. J. (2011). Research methods for leisure and tourism. (4th ed). England: Pearson Education Limited.

Verlag, G. (2013). Gabler Wirtschaftslexikon. Retrieved from http://wirtschaftslexikon.gabler.de.Homepage.jsp

Vohra, V. (2014). Using the multiple case study design to decipher contextual leadership behaviors in Indian organizations. Electronic Journal of Business Research Methods, 12(1), 54.

Voss, C. (2010). Case research in operations management: In researching operations management. London: Routledge.

Vu, P., \& Feinstein, S. (2017). An exploratory multiple case study about using game-based learning in STEM classrooms. International Journal of Research in Education and Science, 3(2), 582588.

Walter, A., Auer, M., \& Ritter, T. (2006). The impact of network capabilities and entrepreneurial orientation on university spin-off performance. Journal of Business Venturing, 21(4), 541567.

Weber, P. G. (2014). Gender related perceptions of SME success. International Journal of Gender and Entrepreneurship, 6(1),15-27.

Welter, F., \& Smallbone, D. (2010). The embeddedness of women's entrepreneurship in a transition context. Retrieved from https://www.researchgate.net/profile/Friederike_Welter/publication/235966803_The_E 
HOLISTICA Vol 11, Issue 2, 2020, pp. 25-51

mbeddedness_of_Women\%27s_Entrepreneurship_in_a_Transition_Context/links/54f44ac 30cf299c8d9e6803d.pdf

Wernerfelt, B. (1984). A resource based view of the firm. Strategic Management Journal, 5(2), 171180. https://doi.org/10.1002/smj.4250050207

Wiklund, J., \& Shepherd, D. (2003). Knowledge-based resources, entrepreneurial orientation, and the performance of small and medium size business. Strategic Management Journal, 24(13) 1307- 1314

Xavier, S. R., Ahmad, S. Z., Nor, L. M., \& Yusof, M. (2012). Women entrepreneurs: Making a change from employment to small and medium business ownership. Procedia Economics and Finance, 4, 321-334.

$\mathrm{Xu}, \mathrm{L}$. (2009). Business incubation in China: Effectiveness and perceived contributions to tenant enterprises. Management Research Review, 33(1), 90-99.

World Bank. (2014). Labor force participation rate. Retrieved from http://data.worldbank.org/indicator/SL.TLF.CACT.FE.ZS

Yimamu, N. (2018). Entrepreneurship and entrepreneurial motivation. Retrieved from https://www.theseus.fi/handle/10024/144307

Yin, R. K. (2009). Case study research: Design and methods (4th ed.). London, England: Sage.

Yusof, S. R. M., \& Aspinwall, E. M. (2000). Critical success factors in small and medium enterprises: Survey results. Total Quality Management, 11(4-6), 448-462.

Zamfir, A. M., \& Hjálmarsdóttir, E. H. (2017). Research \& Development through a gender lens-the case of Romania and Iceland. HOLISTICA-Journal of Business and Public Administration, 8(2), 106-115. 